\title{
THE DEATH OF HENRI V: LEGITIMISTS WITHOUT THE BOURBONS
}

\author{
MARTIN SIMPSON*
}

On 24 August 1883 Henri Dieudonné de Bourbon, the comte de Chambord and Legitimist Pretender to the French throne, who had lived out his adult life in exile, breathed his last in the Austrian château of Frohsdorf. With his death the French Bourbon line came to an end. Legitimism, it seemed, had run its course: the hopes of a restoration, so dramatically revived in the wake of Sedan, had come to nothing and with Chambord's death the Bourbon line itself was extinguished. The prospects facing Legitimists were bleak. The strict logic of succession pointed to the comte de Paris, unpalatable due to the suspect political ideals and the perceived treachery of the Orleanists in general, and the heritage of the comte de Paris in particular, namely the regicide Philippe-Égalité and the usurper Louis-Philippe 'king of the barricades'. The only alternative was to look further afield to Don Carlos, and the Spanish Bourbons, the fantasy of the 'blancs d'Espagne', unless the disillusioned Legitimist converted to the quixotic and bizarre movement of Naundorffism. This tendency held that the Dauphin, Louis XVI, had escaped execution and lived as the comte de Naundorff, Louis XVIII and his brother Charles X having reigned illegitimately As a result many chose to withdraw from political life altogether and, in the words of Steven Kale, Legitimism entered its 'death throes' ${ }^{1}$ With Chambord gone there was nothing left to hold the Legitimist movement together.

It is understandable that the death of the last of the Bourbons should have received little scrutiny. First, in the context of the fall of the Moral Order regime and the stabilization of the Republic, there is little in the fortunes of Legitimism in general after the collapse of the restoration efforts of 1871-3 to detain most historians. Legitimism has no place in the meta-narrative of the enracinement of the Republic. Secondly, it is not an event whose interpretation appears problematic: Chambord's death drew a line under Legitimism. However, I would suggest that this very simplicity is deceptive. In the first place the dilemmas over continuing action that faced the loyal Legitimist in 1883 were in no sense unexpected. It had been apparent for many

- The author is a temporary lecturer at the University of Manchester He wishes to thank Professor Pamela Pilbeam and the anonymous referees of Frencb History for their comments on the first draft of this article.

I S. Kale, Legitimism and the reconstruction of Frencb soctety, 1852-1883 (Baton Rouge, La, 1992). 
years that Chambord was destined to die childless. At a meeting of the comités légitimistes of the south-west held in Toulouse in 1879 , the representative for the Tarn reported that when he spoke of the benefits that 'Henri $V$ ' alone could deliver, peasants would pointedly ask 'Mais après lui?'2 Although Joseph du Bourg, Chambord's personal representative for the entire region of the southwest, approved the answer 'La Maison de la France' as excellent, it was abundantly clear that Legitimism was in this sense a doomed movement. 'L'enfant du miracle' had only postponed the extinction of the Bourbons that the duc de Berry's assassin had intended. Legitimists could not escape the fact that they would soon find themselves bereft of a Pretender.

It is crucial to understand that Legitimism itself was far from simple, but a diverse, complex and even divided movement. Legitimism was not focused on the restoration of the Bourbon monarchy to the exclusion of all other considerations. Stéphane Rials has suggested that Legitimism was perhaps not so much a political phenomenon as a social phenomenon, connected to a set of social ideals that did not neatly translate into any single political agenda. ${ }^{3}$ For many Legitimists, as Steven Kale has convincingly argued, a Bourbon restoration was conceived in social terms. ${ }^{4}$ Legitimist faith did not necessarily mean political activism. Certainly when looking for Legitimist notables, the political organizations of the comités légitimistes are not the best startingpoint; the politically involved were invariably also members of the numerous Legitimist-dominated literary, agricultural, charitable and religious associations, where those Legitimist dignitaries who were not actively involved in politics were to be found. Indeed, the importance of ultramontane Catholicism to many Legitimists ('Catholiques avec le Pape, Royalistes avec le Roi' as the newspaper of Legitimism in the department of the Aveyron, Le Peuple, put it) has led to suggestions that for some Legitimists the focus was as much on Pius $\mathrm{IX}$ as Chambord; increasingly the restoration of the temporal power of the Papacy and the restoration of the monarchy were linked together. 5 This leads to questions over the role of Chambord within the Legitimist movement. If Legitimism was not incarnated in the person of Chambord, then the linkage between his death and the disappearance of the Legitimism movement becomes more problematic. It can in fact plausibly be argued both that, rather than dying with Chambord, Legitimism predeceased him and that it outlived him. We can develop these conflicting arguments if we accept that, as I will argue, Legitimism was essentially a local movement. Using research carried out in two contrasting departments in the Midi-Pyrénées, the Haute-Garonne

${ }^{2}$ S[ociété des] L[ettres de l'] A[veyron] $\mathrm{F}^{11}$ bis 262 et 265 réunis, summary report of meeting of 21 July 1879

${ }^{3}$ S. Rials, Le légittmisme (1983)

4 Kale, Legittmism.

'Michel Denis suggests that during the 1860 s Legitimist despair at any effective action on the part of Henri $V$ led them to look increasingly towards the Pope. 'La question romaine a révélé une monarchie de substitution à laquelie les royaltstes déctarés sont les plus dévoués, au point de réléguer chez quelques-uns le Comte de Chambord au rang du prince mythique' $M$ Denis, Les royalistes de Mayenne et le monde moderne (Lille, 1977), p. 406 
(whose cbeflieu, Toulouse, was a historic centre of Legitimism) ${ }^{6}$ and the Aveyron (strongly clerical and reactionary, a department where Legitimists were elected to the Chamber of Deputies as late as 1889), I examine the impact of the death of the comte de Chambord to ask questions about the nature of Legitimism. ${ }^{7}$

There are powerful arguments for locating Legitimism in the person of Chambord, of which the most obvious is by no means the strongest. Whilst Legitimism's political project was the restoration of the Bourbon monarchy, it might be argued that it was often impossible to follow this project with a great deal of conviction. The Second Empire's apparent durability sapped Legitimist convictions, as testified to by numerous defections, whilst those who kept the faith were divided over political engagement or abstention as counselled by their Pretender. When the operation of divine Providence (a force that loomed large in Legitimist thinking) in the shape of the Prussian army felled the Second Empire, Legitimists ultimately proved incapable of capitalizing upon the exceptional conjuncture of an exhausted France and a monarchical National Assembly. Although the loyal often chose to blame Orleanist intrigues for this débâcle, it subsequently required a strong faith and an incomprehension of the political realities of France to match that of Chambord to believe that restoration remained a credible option. Yet Legitimists were united about the figure of Chambord not solely through their support for him as Pretender, but also in their faith in his person. A defining trait of Legitimism was an ardent personal attachment to Chambord, a sensibility Stéphane Rials identified as 'Chambordisme'. ${ }^{8}$

This reverence for Chambord as a quasi-divine personage is perhaps best expressed by Cornély, editor of the Legitimist newspaper Clarton, in his account of visiting Frohsdorf, where Chambord held court as Henri V. After recounting his journey to Frohsdorf and meetings with members of Chambord's entourage, Comély came to the moment of meeting Chambord himself. He found him 'le français le plus patriote, le plus moderne, le plus éclairé, le plus Français qui se puisse rêver. Et en même temps un diplomate, un soldat, pour tout dire en un mot, un Roi et un grand Roi.' Yet this language, designed to present Chambord as a kingly figure, a true patriot, despite his

\footnotetext{
6 See D Higgs, Ultraroyalism in Toulouse (Baldmore, Md, 1973) Toulouse was at the heart of the entire Legitimist movement in the south-west

7 The choice of departments was motivated by a desire to examine the 'Midi blanc' The HauteGaronne was 2 moderately conservative department (despite the radical orientation of Toulouse) and dermands consideration as the regional centre of Legitimism, whereas the Aveyron was identified as an area of enduring reactionary strength and noted for its high levets of religious practice, the epitome of the traditional rural France with which the Legitimist movement is identified.

'S Rials, 'Contribution à l'étude de ta sensibilité légitimiste le "chambordisme", idem, Révolution et contre-révolution au xix' siècle (1987), 220-30.
} 
exile, and no anachronism, but a potential enlightened modem monarch, gave way to an entirely different tone. Cornély continued: ${ }^{9}$

Ici on me permettra de déposer le crayon du reporteur et de ne pas traduire ... la conversation qui a duré plus d'une heure. Monseigneur ne parlait au journaliste, mais au fidèle, et il me semblerait que je commets une sorte de profanation si j'imprimais ses épanchements du souverain et mes expansions du royaliste.

Intransigent aveyronnais Legitimist Eugène de Barrau (whose inheritance included a carefully preserved piece of paper received by Henri de Barrau in 1838 with Chambord's seal and the simple words 'À Monsieur de Barrau, Henri') was also suitably overcome on meeting Chambord, feeling tears come to his eyes 'devant la majesté des souvenirs vivaces dans l'héritier de tant de rois .. .' Yet for a 'pointu' [intransigent Legitimists were known as 'purs' or 'pointus'] like de Barrau, worship of Chambord was unconditional, and Chambord's personal qualities were ultimately immaterial. His hereditary right was 'ce gage unique de repos et stabilité .. . Gage qui suffirait à lui seul pour suppléer à l'absence de toutes les qualités personnelles dont le prince est si richement doté.'10

In this context the death of Chambord could be nothing less than a tragedy; for fervent Legitimists Chambord was the only hope for France. When in July 1883 Joseph du Bourg acknowledged that Chambord's doctors considered his illness incurable, advocating prayer for the Virgin's miraculous intercession, he wrote: 'Lui seul dans le monde avait prononcé le mot de guerre contre la Révolution. Lui seul pouvait la vaincre et la maîtriser.' ${ }^{11}$ Consequently news of Chambord's illness led to a spectacular display of religious fervour: the comité royaliste de Toulouse declared the necessity of 'une pénitence nationale' and special novena were organized. ${ }^{12}$ Despite this frenzied piety the ineluctable designs of Providence were to take away the last of the Bourbons on 24 August. Legitimists in France who had been united in prayers for his recovery ironically learned this shattering news on 25 August, the Saint-Louis, a day that had been heralded as holding out fresh hopes in its symbolic associations. In a letter to Eugène de Barrau, Joseph du Bourg's brother Antoine sombrely concluded:

Les desseins de Dieu sont impénétrables, mais il faut toute la force de la foi, et tout le secours de la grâce pour s'incliner sans murmure sous la catastrophe que sa justice a infligé à notre malhereux pays. Dans cette nuit profonde qui s'est fait autour de nous, nous voyons

\footnotetext{
' Cornély in Le Clarion, cited in L'Union du Midt, 14 June 1883 L'Union du Midi was consulted in A[rchives] D[ćpartementales de la] H[aute-] G[aronne] at BF 340

${ }^{10}$ SLA F ${ }^{11}$ bis 262 et 265 réunis, draft of Revue Religteuse du diocèse de Rodez et de Mende, 21 November 1871 article

11 Ibid., letter, 5 July 1883.

12 See L'Union du Midi, vartous editions of July 1883
} 
seulement que la France est irrévocablement condamnée à des ruines épouvantables...

For Antoine du Bourg this then was the ruin of France and the close of Legitimism: 'notre action est désormais finie . . . le mandat que nous tenions de la confiance du Roi expire avec lui' ${ }^{13}$ The marquis de Dreux-Brézé ordered the dissolution of the comités légitimistes, and Eugène de Barrau withdrew from political life, whilst Joseph du Bourg, unswerving in his Legitimist purism, pledged his allegiance to Don Cartos of Spain, despite his own admission that it was politically unviable. ${ }^{14}$

For 'purs' any mention of the comte de Paris was repugnant, and de Barrau ended his association with Frayssinous of the Journal de l'Aveyron on account of his article 'Le Roi est mort, Vive le Roi'. ${ }^{15}$ The choice was between political disengagement and 'le terrain absolument catholique', as advocated by de Barrau in the Revue religieuse du diocèse de Rodez et de Mende. As former fellow member of the comité légitimiste de l'Aveyron de Toulza put it, only memories were left: 'Aujourd'hui finissent et les vieilles traditions de ma famille et les rêves de ma vie. Si nous avons eu le culte de fidelité, il nous restera celui de souvenir.' 16 A similar finality was spelled out by the L'Union du Midi, the press organ of intransigent Legitimism, published in Toulouse and read throughout the south-west. On 26 August Georges Maisonneuve, one of the sub-editors, wrote: ${ }^{17}$

Sait-on bien tout ce qui meurt aujourd'hui en France avec M. le Comte de Chambord?

C'est d'abord le sentiment du respect . . .

C'est peut-être aussi le vieil honneur chevaleresque et français dont il était la plus fière incarnation . . .

C'est l'autorité dont il représentait le principe.

C'est l'ensemble sacré des traditions cbrétiennes et nattonales résumées en lui et qui par lut auraient refleuri sur le vieux sol frangats.

The last edition of L'Union du Midi was published on the day that saw Chambord interred at Goritz, and a short statement from the direction announced 'nous brisons . . . cette valiante épée de combat . . . et, enveloppant ses débris dans les plis du drapeau blanc qu'elle a toujours défendu, nous les

13 SLA F ${ }^{11}$ bis 262 et 265 réunis, letter, 26 Aug. 1883.

14 A[rchives] N[ationales] $\mathrm{F}^{7} 12431$

15 SLA $F^{11}$ bis 262 et 265 réunis, letter, 28 Aug. 1883 Frayssinous defended his position and cuttingly wrote 'J'à ćcarté de la mémoire du Prince toute affirmation de responsabilité au sujet de la situation politique que nous subissons; et certes, j'al fait effort pour ne pas laisser échapper de ma plume d'amères et cruelles réflexions.'

16 Ibid., letter, 27 Aug. 1883

17 - I'Union du Midi, 26 Aug. 1883 (author's italics). 
déposons auprès du cerceuil de notre Roi'. With Chambord departed their hopes was now turned heaven-wards: 'En nous inclinant devant le chef de la Maison de France, nous supplions Henri V d'intercéder, du haut du Ciel, en faveur de notre malheureux pays, afin que Dieu le préserve des catastrophes suprêmes dont menace la Révolution. ${ }^{18}$

Yet another persuasive line of argument places an entirely different interpretation on Chambord's death, identifying not so much an end as a footnote. This argument is in fact most often made implicitly rather than explicitly. General histories of the period, most notably François Furet's Revolutionary France 1770-1880, focus almost exclusively on the advent of the republican Republic, conceptualized by Furet as the reunion of the republican country with its tradition'. ${ }^{19}$ This 'republican destiny' reading of the Third Republic inevitably marginalizes Legitimism's place within the early years of the Third Republic. Indeed, the strong implication is that the conditions which made the abortive restoration efforts of $1871-3$ possible were a bizarre aberration. Once the ignominious failure of Legitimists to prevail on Chambord to compromise over the tricolour has been recounted, the narrative of the coming of republican France can proceed. The death of Chambord may receive a passing mention a few pages later, evidently Legitimism, as a political movement of any consequence, died well before Chambord, condemned to extinction by his obstinacy and intransigence. The shattering republican electoral victory of 1881 , triumphantly confirming the 1877 elections that followed the Seize Mai, the 'town-hall revolutions' of 1878 and the senatorial elections of 1879 , all make the political irrelevance of Legitimism in the grand narrative of the stabilization of the Third Republic apparent.

Whilst Furet's somewhat 'whiggish' approach to the Third Republic can be questioned, it is hard not to accept the overall verdict on Legitimism. legitimism did rapidly become marginal, fading from the political scene during the period of 'la république des ducs' and many of the 186 Legitimist deputies elected in 1871 chose not to stand again. Those who did were decimated in the elections of 1876-7, leaving a mere eighteen of them. The only evidence of any significant strength or dynamism on the right came from the revitalized Bonapartists; in the Haute-Garonne the Bonapartist vote in both elections exceeded 35 per cent of the total votes cast. ${ }^{20}$ However, Legitimism's dire

18 L'Union du Midi, 3 Sept. 1883.

19 F Furet, Rewolutionary France 1770-1880 (Oxford, 1992), p 537 For a good example of a history of the Third Republic in this mould: J.M Mayeur and M. Reberiour, Tbe Tbird Republic from its origins to the Great War (Cambridge, 1987)

${ }^{20}$ AN C 3482; Robert, Bourtoton and Cougny, Dtctionnatre des parlementatres frangats 1789 1889 (1889-91). The combined votes cast for the five Bonapartist candidates, the comte d'Ayguesvives, Niel, Lenglé, Tron and Oldekop amounted to 37.5 per cent in 1876, and 356 per cent in 1877 . 
electoral fortunes are not the total sum of this argument; there is also the issue of the relationship between Legitimism and the France of the late nineteenth century. Furet sees a clear incompatibility and delivers a telling verdict: 'uprooted by the French Revolution, royalty had never retrieved its place and its past, of which the Church, also uprooted, constantly offered it the illusion. French monarchy in the nineteenth century had lived in the myth of its own tradition . . 21 This view is by no means unprecedented and Furet is quick to remind his readers that contemporaries were sceptical; early in 1871 Renan judged that the Bourbon monarchy had become 'impossible'. ${ }^{22}$ Chambord's actions lend weight to this idea. The events of 1871-3 suggest that it was less Chambord's lack of an heir as his perverse and inflexible attitudes - attitudes which, as Halévy caustically remarked, owed little to the traditions of Henri IV for whom Paris was worth a mass - that doomed the Legitimist movement. In this reading Chambord was a little more than a symbol of a tradition that lacked any relevance to the political realities of the day and his death marked the final close of an anchronistic politics whose bankruptcy and impotence had been amply confirmed

The concept of Legitimism as anachronistic is a crucial one, posing an intriguing question: was Legitimism impossible even with a more tractable Pretender? Steven Kale argues that the drapeau blanc débâcle, absurd as it might seem, was in fact perfectly consistent with Chambord's position and the principles of intransigent Legitimism overall. Chambord's pronouncement, 'La parole est à la France, l'heure est à Dieu', made his position clear. In his vision a restoration was to be by acclamation, free of any conditions, not by the grace of an elected assembly, especially not an assembly elected by universal suffrage, which most Legitimists held not to be the true expression of the nation's opinion but, in the words of Pius IX, 'the universal lie'. Chambord's manifesto of 1871 promised 'le contrôle des deux chambres' and 'le suffrage universel honnêtement pratiqué', but the Legitimist understanding of these concepts kept the locus of power firmly out of the hands of the representatives of the people. As Stéphane Rials, writing in 1983, elegantly put it: ${ }^{23}$

L'attitude du Comte de Chambord, si volontiers tournée en dérision aujourd'hui, était d'une absolue logique au regard des principes qu'il croyait incarner. Ce qu'il rejetait dans le drapeau tricolore c'était la souveraineté nationale, le libéralisme, le parlementarisme et peut-être au-dèla tout un pan de la sensibilité moderne rationaliste et anthropocentrique. Ce qu'il voulait défendre, avec le drapeau blanc, c'était une certaine idée de la monarchie paternelle et chrétienne, temperée par l'amour et la religion plus que par tel ou tel mécanisme constitutionnel abstrait.

\footnotetext{
${ }^{21}$ Furet, Revoluttonary France, p 510

22 lbid $p 508$.

${ }^{23-}$ Rials, Le léğttimisme, p. 86
} 
Thus the reading of Chambord's death as footnote identifies the politically fossilized agenda of Chambord - and many of his followers - as what made Legitimism unworkable. This is supported by the defence of Chambord's actions offered in the final editions of $L$ 'Union du Midi, blaming France for having proved itself unworthy of Chambord, with the result that 'l'heure de Dieu est venue, non pas dans la splendeur de ses promesses, mais dans toute la rigueur de ses châtiments'. ${ }^{24}$ The restoration as offered in 1873 would have represented a betrayal of Legitimism, argued Miles on 30 August. If he had accepted:25

On l'eut bafoué pour ses complaisances. Au lieu d'être une haute et vieille idée gardant absolument le droit de mépriser les faits, le Comte de Chambord n'eut été qu'un ambitieux vulgaire, pliant ses allures et conformant ses paroles aux fantaistes, même injurteuses de ses électeurs. Son non possumus fut éclairé et magnamine.

The idea that Legitimism did despise - or at the very least fundamentally misunderstand - the political realities of late nineteenth-century France is advanced by Robert Locke in his perceptive study of the Legitimist deputies of 1871-6. Locke argued that the classic view of Legitimists as backward and antimodern in their attitudes towards industrialization and capitalist exploitation was mistaken, as much on the grounds that there is no intrinsic link between liberalism and successful industrialization, as on the evidence of Legitimist entrepreneurs such as Benoist d'Azy. The failure and archaism of Legitimism lay rather in their conception of 'moral order' that neglected to accommodate the great fact of the Revolution, and was hence inoperable in the liberal-democratic society that the Revolution had bequeathed to nineteenth-century France. ${ }^{26}$ The clear-sighted Hervé of Le Solell had written:27

La monarchie ne sera pas, ou elle sera constitutionnelle.

La monarchie ne sera pas, ou elle sera moderne.

La monarchie ne sera pas, ou elle sera populaire.

Legitimism, as represented by Chambord, did not even aspire to the first requirement and, despite all efforts to argue the contrary, did not fulfil the second as understood in the France of the Third Republic. In the light of this it is scarcely surprising that the third requirement also eluded the Legitimists.

I I I

The attitude of the intransigents of the comite légitimiste de l'Aveyron and the pronouncements of L'Union du Midi point to 24 August 1883 as the end of

24 L'Union du Midi, 2 Sept 1883

2s L'Union du Midi, 30 Aug. 1883 (author's italics)

${ }^{26}$ R. Locke, French Legittmists and the politics of moral order in the earty Tbird Republic (Princeton, N J , 1974)

${ }^{27}$ Herve in Le Solell, cited (and attacked) in L'Union du Midi, 7 May 1883 
Legitimism, a view endorsed by Stéphane Rials; standard accounts of the Third Republic implicitly take 1873; and even Steven Kale, who has recently taken it upon himself to resuscitate Legitimism, concedes that it was 'a right that did not continue'. Whatever echoes of Legitimism persisted - and some would find a Legitimist stamp to the organicist conceptions of Vichy - Kale analyses the Legitimist movement as progressively splintering after the failure of the restoration efforts, before disintegrating altogether with the loss of Chambord. However, it is possible to argue the reverse, suggesting that although 1883 may have required a certain readjustment, it was in no way the end. In fact, for those moderates who had wanted Chambord to abdicate in favour of the comte de Paris, a man whose very heritage was the tricolour (as restored by LouisPhilippe), 1883 might even signal a new beginning. Certainly the dissolution of the comités légitimistes was far from permanent, as the 1884 Schnerb report makes evident. This report, an extensive analysis of the state of the royalist party, found that the vast majority of monarchist newspapers - 130 out of 143 - recognized the comte de Paris as legitimate Pretender to the throne and that the eclipse of the comités légitimistes had been temporary. Despite DreuxBrézé's decree, in some departments the comités légitimistes simply continued to function, transferring their allegiance to 'Philippe VII', whilst elsewhere the comités royalistes that emerged included former members of the comités légitimistes. ${ }^{28}$ In only thirteen departments was there was no activity to report and only thirteen departments saw Legitimists dissent from this general acceptance of the comte de Paris. ${ }^{29}$ Moreover the new structures of the parti royaliste, which included the innovation of missi dominict to liaise with the provincial comités and used the networks of the cercles catboliques and syndicats agricoles, were far more sophisticated than those that had existed under Chambord. ${ }^{30}$

Thus the Haute-Garonne comité had reformed under the leadership of Comte Victor d'Adhémar, former member of the comité légitimiste and Georges Maisonneuve, former subeditor of L'Union du Midi revived the newspaper as L'Union du Languedoc. In fact Maisonneuve even published an open letter to Schnerb declaring 'Ce parti reconnaît pour chef $M$. le Comte de Paris et se propose pour but le renversement prochain de la République. ${ }^{31}$ Moreover, perhaps contrary to expectations, even among the ranks of the

28 AN F 12431

29 For 2 more detailed breakdown of the Schnert questionnaire S Osgood, Frencb royalism since 1870 (The Hague, 1970)

${ }^{30}$ AN F $^{7} 12477$, report of directeur de la Sûreté gếnérale, 26 Sept. 1887 Also W. Irvine 'Royalists, mass politics and the Boulanger affair', Fr Hist, 3 (1989), for a discussion of royalist organization under the comte de Paris

${ }^{31}$ AN $F^{7} 12431$, L'Union du Languedoc, $7 \mathrm{Mar} 1883$ Les Nouvelles, another Legitimist publication that had switched its support to the comte de Paris, was more circumspect; some held that taking the provocative line of Malsonneuve was to risk prosecution on the charge of attempting to foment unrest. However, comment on the Scherb questionnaire was common and the material in AN includes clippings from many monarchist publications mocking the directeur of the Sûneté genérale, responding with their own reports about the state of the local royalist party or 'expressing their contempt for the method of turning the prefets into 'mouchards' 
'chevau-légers' (as the intransigent Legitimist deputies of 1871-6 were known) examples of leading Legitimists who were ready to sponsor the comte de Paris are not hard to find. Gabriel de Belcastel, former senator for the HauteGaronne, and the distinguished Albert de Mun, who famously proclaimed 'Nous sommes la Contre-Révolution irréconciliable', were swift to rally publicly to the comte de Paris, in both cases motivated by the wish to prevent divisions over this issue. In the Corrèze, the baron de Iaprade, former local representative of Chambord, declared, 'moi intransigent blanc qui n'a jamais faibli, je me range au parti du roi des barricades. Les enfants ne sauraient pas être responsables des fautes de leur père - à tout péché, miséricorde! ${ }^{32}$ If Legitimist political success at a national level was, to say the least, elusive after the Seize Mai, it did not necessarily indicate the cessation of Legitimist political activity. Indeed, the Aveyron may have lacked the structure of a comité royaliste, but it did not lack royalist candidates: Legitimists de Montéty and de Benoit successfully stood in 1885 and 1889 , whilst on a local level Victor de Bonald and Henri de Valady, former Legitimist deputies, continued to win reelection as conseillers généraux.

The issue of political activism, however, is far from simple. There are obvious objections to the argument that continuing political activity on the part of local Legitimists proves the persistence of Legitimism. First there is the difficult question of whether those who did choose to continue to contest elections - unsuccessfully in the Haute-Garonne, successfully in the Aveyron - did so as Legitimists. Did adopting the compromise stance of l'union conservatrice, setting aside the whole issue of monarchy to focus upon 'la défense sociale et religieuse', signal a betrayal of Legitimist principles? Secondly there are questions about the nature of Legitimism. It might be argued that what was crucial was not so much the national level as the local level. The social ideals of Legitimism were those of decentralism and Christian patemalism, chiefly concerned not with the national dimension but the local dimension. ${ }^{33}$ The key concern was how social relations functioned at the local level, with an idealization of the ancien régime of counter-revolutionary imagining that saw close relations of deference and responsibility that tied a local nobility/notability to their social inferiors. The ideal of the local seigneur providing protection and aid for his suitably deferential tenants, an ideal nourished by Legitimist works of history and romantic fiction, was one that exercised a powerful hold over the Legitimist imagination. André-Jean Tudesq argued that the Legitimist ideology, 'une conception morale et non sociale de la société', was rooted in a mythologized past, the anclen régime 'reconstruit idéologiquement'..$^{34}$

${ }^{32}$ AN F' 12431.

${ }^{33}$ See S Hazareesingh, From subject to cittzen (Princeton, N.J, 1998), for a clear explanation of the place of the local dimension and decentralization within the Legitimist ideology

34 A.J Tudesq, Les grands notables en France, 1840-49 (2 vols, Bordeaux, 1964), i. 211. 
Tudesq's work also proved that the scale of the 'émigration à l'intérieur' in the wake of the 1830 revolution had been much exaggerated; despite the claims of René Rémond it appears that Legitimists did not retire en masse, continuing to play a significant local role. ${ }^{35}$ Legitimism was thus in many ways a local phenomenon and it is on the local level that we should look for continuing Legitimist influence and action. Indeed, focusing on the local level allows an interpretation of the result of 1871 as not a bizarre by-product of extraordinary political convulsions, but as a perfectly logical expression of a solid local power that had been assiduously built up from the 'émigration à l'intérieur' onwards. Steven Kale makes precisely this case, noting that of 957 non-Bonapartist conselllers généraux in 1870, 415 were Legitimists, making them the largest political tendency represented..$^{36}$

The issue of whether the focus of Legitimism should be local or national was a crucial one during the Second Empire. The local level was in many ways preferable. First, Legitimists were vested with a considerable local strength that they had successfully conserved through the July Monarchy and the Second Republic. Secondly, and more importantly, although strength in the consell général was a good indicator of this enduring local power, local influence did not require political involvement. Roles as maires or conseillers généraux denoted local influence rather than conferred it. Legitimists had traditional means of local influence, often related to their standing as grands propriétaires and their prominent role in paternalist charitable and religious associations such as the Conférences de Saint-Vincent de Paul. In the context of the national dominance of Bonapartism, and the comte de Chambord's instruction for Legitimists to abstain from political engagement, such social activism was hailed as the answer by the comte de Falloux: ${ }^{37}$

It is not enough to formulate decrees on the past and prognostications on the future; we have to moralize villages and towns to combat revolutionary influences and to found and develop religious institutions. The field still remains an immense one. All the strength of the old royalist party and all which it is famous for may be displayed in this, with great honour and great profit to France.

Fulfilling the role of a responsible local notabilty did not merely conserve intact the traditional Legitimist clientele, but was also crucial to their self-identity. In areas where Legitimists could plausibly claim to provide an unchallenged local leadership that was looked to for guidance and protection, ideology and reality intersected, assuring Legitimists that the essence of France was Catholic, monarchical and hierarchical. In pursuing this local agenda Legitimists were, in the analysis of Steven Kale, following their key goal, the rechristianization of French society.

39 R. Rémond, Histoire des Drottes en France (4th edn, 1982) Rémond refers to the penod 1830-71 as 'quarante ans d'abstention' for the Legitimists.

${ }^{36}$ Kale, Legitimism.

${ }^{37}$ De Falloux, Memoirs of a royalist, trans. Pitman (2 vols., 1888), ii 156 
Political involvement on the national stage offered no such attractions. There were rather several dangers: first, the tactic of working within Bonapartism could lead to defections - in the Haute-Garonne, for example, the comte d'Ayguesvives, made an écuyer de l'impératrice, was permanently converted to the imperial cause ${ }^{38}$ - and secondly, working against Bonapartism often required compromising coalitions. ${ }^{39}$ Indeed the politics of the Union Libérale ultimately went beyond compromising coalition politics; in trying to widen the appeal of Legitimism by pressing for liberal reforms in concert with Orleanists and republicans, liberal Legitimists took a political stance directly at odds with the principles of their Pretender. Neither Chambord nor the intransigent Legitimist majority could countenance parliamentary sovereignty and universal suffrage; as Rémond observed, the most accurate statement of their political principles came in 1864 with Pius IX's programmatic rejection of the nineteenth century, the Syllabus of Errors. ${ }^{40}$ Tellingly Legitimist deputies were to organize an address in 1871 congratulating Pius LX on the 'grand et courageux Syllabus qui garde toute la vérité sociale'.

It was on precisely such an agenda that the most significant Legitimist political mobilization of the 1860 s was to occur. The Legitimist opposition that emerged in the late 1860 s was concerned not with the liberal and decentralist agenda of the Union Liberale, but the temporal rights of the Papacy and Catholic liberties. Ultimately Legitimism under the Second Empire was not merely at odds over the question of political engagement, or the local versus the national, but ideologically divided. A liberal minority was willing to pursue a liberal agenda of compromise that could stretch to include Orleanist ideas of a constitutional parliamentary monarchy, ranged against whom were those to whom the notion of such a compromise signified a negation of all the principles incarnated in the legitimate monarchy. The liberalism of de Falloux, who believed that Legitimists had to find a way to accommodate the fact of the Revolution, ${ }^{41}$ was anathema to the ultramontane intransigents. The abbé Morel, contrasting de Mun and de Falloux, attacked the latter as 'un homme d'entredeux ... un homme d'un croisement qui n'a pas encore existé; un métis de la Révolution et la Contre-Révolution'. ${ }^{22}$ As Hazareesingh argues, modern

39 ADHG 3M 222

39 On the issue of Legimist politics under the Second Empire S Kale, 'French Legitimists and the politics of abstention, 1830-1870', Fr Hist Stud, 20 (1997), 665-701

40 'L'idée de restauration n'en est pas moins la note dominante du système de pensée légitimiste le système se formule en un mot. contre-révolution

c'est peut-être un document de caractère religieux, le texte du Syllabus aux anathèmes duquel ils souscrivent volontiers, qui présente le meilleur exposé de leur pensée 'Rémond, Histoire des Drottes, p 128

i1 De Falloux wrote to Dupanloup in 1872 . 'Si on rejette tout, le bien comme le mal, depuis 80 ans, on se place en dehors de la Restauration et l'on va bien autrement loin que le comte de Maistre

on ne peut la [la Révolution] supprimer ni du passé, ni du présent, ni de l'avenir Ne pas savoir cela ou l'oublier, c'est se placer en dehors des notions les phus élémentaires de la politique et du bon sens' J Gadille, La pensée et l'action polittque des évêques franfaís au début de la III République 1870/1883 (2 vols, 1967), i. 85.

42 J. Morel, M. de Mun et $M$. de Falloux (1879), p 8 
legitimist discourses were constantly subverted by an older discourse of subjects, subordination and hierarchy. ${ }^{43}$

\section{V}

Examining Legitimist political activity in the Second Empire makes it clear that it is possible to construct three plausible alternative arguments about the relationship between the demise of Chambord and the demise of the Legitimist movement because Legitimism was a divided and contradictory movement. As a movement whose ideology did not translate into any simple brand of politics, and as a movement which lacked any effective political direction (the Second Empire had witnessed a widespread repudiation of Chambord's directives on abstention), Legitimism was incapable of agreeing on a single political strategy. The experience of the Second Empire revealed that Legitimism was pulled in diametrically opposite directions, between a backward-looking and traditional politics, conceptualized by its champions as a politics of Legitimist purity, and between a moderate liberal forward-looking politics of compromise, ready to adapt to the changing nature of politics. ${ }^{44}$

The issue of the politics of compromise versus the politics of Legitimist purity is illuminated by examining the action of the comités légimitistes. The evidence of the correspondence of Eugène de Barrau, head of the comité légitimiste de l'Aveyron, provides a very detailed image of a comité légitimiste in an overwhelmingly clerical and reactionary department, which continued to elect Legitimists until 1889. De Barrau was in regular contact with Joseph du Bourg (Chambord's representative for the entire south-west region) and his brother Antoine du Bourg, and his correspondence has the strength of allowing us to identify general strategic considerations beyond local concerns. The first point that emerges is that the comite légitimiste was determined that Legitimists should be a powerful force in local politics, contesting all elections. Circulars on the need for organization and the need to ready themselves for forthcoming elections, from municipal to senatorial, decisively indicate that the Legitimists were determined to engage politically. However, successive elections cruelly exposed the limits of their influence and the power of the comité. The central issue was that of conservative union. De Barrau's decision to stand as a lone independent in 1871 made his position clear, whilst the experiences of 1871-3 left men such as Joseph du Bourg equally convinced that alliances with the Orleanist centre-right were fatal. In the context of the Seize Mai du Bourg warned: ${ }^{45}$

C'est pour nous un devoir de rappeler que $M$. de Broglie est celui dont l'action perfide mais cachée a fermé en 1873 la porte de la

43 Hazareesingh, From subject to clitien

4H Hazareesingh persuastvely argues that the Second Empire must be seen as a turning-point in the culture of politics', an era during which the practice of universal suffrage in France became normalized.

${ }^{45}$ SLA F ${ }^{11}$ bis 262 et 265 réunis, letter, 2 June 1877 
France au roi, qu'il est le chef de ce centre-droite où se perpétue la tradition de 1830, tradition de révolution, d'intrigues, d'ambitions égoïstes et de haines contre la légitimité.

Conservatism was at best deeply suspect, and at worst actively worked to the ruin of Legitimist hopes. A note of 1876 therefore fulminated against 'l'élasticité du mot "conservateur," la mystification qu'il recouvre' that had facilitated the election of Mayran and Delsol, representatives of 'la révolution Orléano-Bonapartiste'. ${ }^{46}$

Yet the evident impossibility, of finding Legitimist candidates with a realistic chance of success in every circonscription complicated matters. On the one hand, not putting up candidates seemed an admission of weakness, whilst on the other incidents such as the risible showing of the vicomte d'Armagnac in 1876 (standing against the Bonapartist Azémar in the first Rodez circonscription he received 419 votes -3.9 per cent) only served to discredit them. These were recognized problems; an 1877 circular from the bureau des députés royalistes required information on royalist candidates who might succeed with administrative support, conservative candidatures which threatened royalist interests, and the possibility of finding non-threatening conservative candidates to oppose them. ${ }^{47}$ It was, however, not merely a case of non-threatening conservatives; ironically the few successful Legitimists were deemed suspect. In 1877 the comité départemental approached Antoine du Boung, brother of the influential Joseph du Bourg, close friend of Eugène de Barrau and regular visitor to the Aveyron, asking him to stand against the Millau sortant de Bonald. Du Bourg excused himself, on the grounds that he was not widely known, whilst de Bonald was not only well established but also assured of the administration's support; de Bonald's candidature was therefore grudgingly accepted as 'inévitable et peu satisfaisante' despite the engagements he had taken before the Millau branch. ${ }^{48}$ Although he had not been prepared to stand against de Bonald, Antoine du Bourg evidently shared the comité's reservations and in the electoral manoeuvrings of 1880 he wrote to de Barrau: 'Il y aurait de plus, àuprès de gens comme Valady et de Bonald, qui se plaignent que le parti est mort dans l'Aveyron, avantage à leur faire sentir qu'ils se trompent et leur faire comprendre qu'ils ne peuvent rien contre nous, ou sans nous.' 49

The story of the fortunes of aveyronnats Legitimism, as read through the correspondence of Eugène de Barrau, reveals the fundamental inability of the comité légittmiste to find candidates whose Legitimist credentials were satisfactory, or to construct alliances with other reactionaries on acceptable terms. Increasingly the suggestions put forward smacked of a dangerous level

46 Ibid., note s.d.

77 Ibid., 9 June 1877, circular. However, Joseph du Bourg and de Barrau were both wary of this Comité de la Drotte, which confirmed their worst suspictons by sponsoring the liberal Pradié.

is SLA $F^{11}$ bis 528, 20 July 1877 and 8 Aug. 1877, letters. Any sign of moderation was suspect; Antoine du Bourg expressed himself 'péniblement surpris' to find that Boisse had not voted with other deputles of the extreme Right in May 1874.

क Ibłd, 23 Mar. 1880, letter. 
of self-deception, if not outright delusion. For instance, in 1879 Antoine du Bourg suggested an electoral alliance with Barascud in Saint-Affrique, provided Barascud would accept their direction. As Barascud enjoyed an entrenched position of considerable strength and held Orleanist attitudes which du Bourg viewed with deep distaste, there was little evidence to believe that he would find this an attractive prospect Again and again it was asserted that if they took the lead, Legitimists could construct alliances on 'le terrain religieux et social' with a minimum requirement of a readiness to support a restoration, should the eventuality occur. In 1881 du Bourg insisted, 'nous sommes en situation de la faire, car si nous ne sommes pas assez forts pour triompher tous seuls, nous le sommes assez pour faire échouer d'autres listes conservatrices'..$^{\circ 0}$ There was, however, remarkably little evidence to support this assertion. In fact it seems that there was no possibility of putting up Legitimist candidates to sabotage untrustworthy conservatives. The issue was rather that of putting up Legitimist candidates to prove that Legitimism was still a credible political movement. After unsuccessful efforts to persuade local Legitimist notables de Toulza or de Castelnau to stand in Saint-Affrique, Antoine du Bourg found himself wondering whether it was worth posing abbé Vernhet's candidature, 'assurée d'un insuccès complet'. Commenting on de Montéty's refusal to stand in Millau in 1881 du Bourg gloomily observed: ${ }^{51}$

Je crois que partout vous serez réduits à assister en spectateur à la lutte et que vous serez contraints observer l'abstention. Évidemment c'est fâcheux, parce que la cause de cette attitude ne trompera personne et que dans nos campagnes nos populations catholiques seront obligées de se jeter vers le bonapartisme qui seul engagera la lutte contre la République.

A circular of March 1881 confirmed that the situation in Aveyron was by no means unique: the comte de Chambord's preference for abstention rather than involvement in the unsavoury politics of the Union Conservatrice as practised in 1876-7 was made clear. It was earnestly claimed that 'l'abstention motivée et expliquée ne voulant pas dire l'inertie, faiblesse ou découragement, mais signifiant protestation contre les mensonges du suffrage universel, signifiant résolution de lutter contre la révolution, signifiant surtout discipline'.$^{52}$ These claims could not disguise the fact that abstention-especially as not appreciably observed by any substantial proportion of the electorate - could hardly fail to be read as an admission of political impotence. It was in fact a classically Chambordist position, a retreat to the dry rock of principle whence intransigent Legitimists were never to return: 'Ce n'est pas vers un succès

so Ibid, 29 May 1881 , letter.

31 Ibid., 21 July 1881, letter

52 SLA $F^{11}$ bis 262 et 265 rénis, note of March 1881 It was stated that where abstention could not be assured owing to the desire of royalist partisans to take part in elections or owing to the risk of being misinterpreted, it was strictly forbidden to support anything other than 'candidatures nettèment et sincèrement róyalistés'. 
électoral que nous devons tendre, mais c'est un acte de vie que nous devons faire, c'est une affirmation que nous devons produire, ne nous préoccupant que de la valeur du principe que nous mettons en avant. ${ }^{.53}$

If the comités légitimistes, then, were concerned with creating a strong political movement, the conclusion must be not only that they failed to do so, but that despite their hopes and schemes, during the period from the Seize Mai to the death of Chambord they were in no sense effective. Du Bourg cautioned that placing themselves on exclusively monarchical terrain risked seeing the anti-republican struggles take place outside their orbit, but the truth was worse still - even what actual Legitimist electoral activity occurred mostly took place outside their orbit. The most well-known and successful Legitimist candidates, Henri de Valady and Victor de Bonald, were conspicuously men they did not trust, men who, in contrast to de Barrau, had engaged in the Union Conservatrice, standing as candidates of MacMahon in 1877. But I would suggest that this state of affairs was not untypical, looking at the evidence yielded by some of the correspondence of the great Toulousain cbevau-léger and senator, Gabriel de Belcastel. The letters of comte Victor d'Adhémar (future representative of the comte de Paris for the south-west region) to de Belcastel give us the other side of the picture. Whereas de Barrau was in accordance with du Bourg and the men of L'Union du Midi in his belief in an uncompromising stance, d'Adhémar was more of a political realist. Thus in 1877 he was apprehensive over the issue of obtaining official support, appalled at the prospect of Brettes-Thurin opposing the entrenched Bonapartist Charles Niel and feared - correctly as it turned out - that Legitimist chances were slim: 'nous serons donc très maigres et très pauvres. Au fond il n'y a que Villefranche où nous ayons quelque chance ... II $\mathrm{y}$ aura là $\mathrm{M}$. Lamothe et $\mathrm{M}$. Lamothe pour répresenter à lui seul tout le parti légitimiste au département est fort humiliant. ${ }^{54}$

It became increasingly apparent to d'Adhémar that his fellow Legitimists were politically blind. When the Ecbo de Provence chose to attack de Broglie during the Seize Mai with approval of Christophe du Bourg, head of the HauteGaronne comtté légitimtste, he wrote exasperatedly:5s

Nos amis sont absolument insensés ... Les raisons ne sont rien pour eux, les faits encore moins. La fantasmagorie, les grands mots creux, les phrases toutes faites, voilà ce qui leur plaît ... Ils ne croient pas qu'il faille absolument former l'union conservatrice, ils se soucient à peine de la Préfecture et de ses influences, ils prendraient pour candidat n'importe qui au hasard du tirage à sort ... On fait détester le Roi en s'isolant ainsi dans les instants périlleux et en ne sachant pas reconnaitre le part de bien et de noblesse qui se trouve dans les hommes chargés aujourd'hui ... de sauver leur pays.

33 Ibid.

s4 ADHG 1J 1370, letter s.d.

ss Ibid, letter s d 
D'Adhémar later despaired of the Comité de l'Union Conservatrice, formed by the majority of the consell général in 1878 to elect suitably conservative candidates to the Senate. He judged it 'pire que mort' and saw Courtois de Viçose (Bonapartist and future head of the comité réactionnaire of 1885) as the sole member capable of taking initiative. Of the role played by the leaders of the comité légitimiste he was scathing:56

quant à du Bourg et Maignon, ils courent au diable comme toujours . . . Ils ne savent pas ce qu'il y a à faire [et] ils en concluent qu'il ne faut rien faire. Si nous les poussons ils bondiront contre nous et nos amis d'importance; ils ne connaissent personne, ne disent que de bêtises et voilà comment le temps passe.

Moreover, as in the Aveyron, it would appear that the comité légttimiste lacked control of the movement in the Haute-Garonne. Certainly the overall involvement of Gabriel de Belcastel seems to have far outweighed that of Christophe du Bourg. Whereas the former organized meetings to discuss the décrets (the decrees dissolving the Jesuits and other non-authorized religious congregations) and appealed for unity in face of the threats to religious liberties, the latter presided over Legitimist banquets and assiduously attended the Legitimist commemorative ceremonies. ${ }^{57}$

It is hard to imagine that d'Adhémar can have mourned the departure from politics of the du Bourgs occasioned by Chambord's death. As a man who had complained of 'l'impossibilité de guérir les comités imbéciles qui nous dirigent' the departure of the intransigents must have been in many respects a profound relief. ${ }^{58}$ A pragmatist, who had been ready to recognize the strong argument in favour of supporting MacMahon and de Broglie, d'Adhémar now found himself at the head of a rejuvenated comité royaliste de la Haute-Garonne. Member's included former deputies Sacaze and Depeyre, whose Legitimist sympathies had faltered to the point where both were considered Orleanists. ${ }^{59}$ Though wary of a slide to the centre-right, d'Adhémar continued to be politically active into the $1890 \mathrm{~s}$. However, there are serious questions to be asked about this continuing political engagement. First, can it truly be termed 'Legitimism without the Bourbons'? Secondly, should we see a continuity rather than a sharp change - were men like d'Adhémâr in the Haute-Garonne and de Bonald in the Aveyron pursuing a politics that they had followed since the installation of the Moral Order regime of MacMahon after the failures of 1871-3? At that

$\$ 6$ Ibid., letter $5 \mathrm{~d}$.

7 ADHG 4M 95-7. Du Bourg presided over the great Legitimist banquet of 9 October 1882 which gathered 1,200 guests and was attended by Godlenski of L'Union and Comély of Le Clarton There is only one report of an actual meeting organized by the comite légitimiste - a dectdedly aristocratic gathering in January 1881

\$DHG 1J 1370, letter s d.

59 Although classified as Legitimists in 1871, both men subsequently deviated substantially. Depeyre was seen as politically suspect by Joseph du Bourg, believed to have acted against Legitimists as minister for justice under de Broglie, whilst Sacaze was elected to the Senate as a Bonapartist candidate in 1876 Robert et al, Dictionnaire. 
time d'Adhémar saw the absolute necessity of the Union Conservatrice and was candid enough to analyse the failure in terms closer to those of Falloux than du Bourg. If the assembly had been too 'parliamentary' to leave the nature of the regime to the restored king, he wrote to de Belcastel in 1875, 'et d'un autre côté, disons le entre nous, le Roi a eu le tort de ne jamais s'inquiéter pratiquement des élements excellents qui composaient l'assemblée. II la tenait en trop grand dédain, et sur ce point ses journaux et ses conseillers l'ont aveuglé. 60

The fundamental point is that the divisions made concrete by Chambord's death were not only well in evidence before this point, but that they had also hardened. The comités légittmistes embodied a Legitimism that took an allornothing stance that was unworkable in both the moderately conservative Haute-Garonne and the solidly clerical Aveyron. Despite their strenuous efforts to construct an effective political force, the comités were ultimately embroiled in unrealizable schemes that tended to an increasing political immobilism. Theirs was a Legitimism of commemoration and fidelity, centred on their celebration of their principles and their veneration of Chambord. Well before the death of Chambord the more moderate Legitimists had, disavowing neither their Legitimism nor their respect for Chambord and his loyal representatives, engaged in the politics of compromise.

V

These political divides within Legitimism lead us first to pose difficult questions about Legitimist political identity, and then in turn to ask further hard questions about the very nature of Legitimism. The fundamental question must be 'what Legitimism meant' after the death of Chambord. Only if we can identify a distinctive Legitimist cast to Legitimist activity in the wake of Chambord's death can we truly identify a genuine 'Legitimism without the Bourbons'. In the case of continuing political activism this is, to say the least, problematic. The lack of any clear consensus on Legitimist politics makes it hard to argue conclusively whether the moderate politics of compromise adopted well before Chambord's death can be identified as 'Legitimist politics'. As I shall argue, we must keep in mind the concept that Legitimism was both more and less than a political movement and ultimately looked beyond politics to construct a satisfying argument about 'Legitimism without the Bourbons'. Politics, however, as the basis for the simple argument that Legitimism adapted and continued after the death of Chambord, must form the starting-point of this enquiry.

Certainly there can be no question that d'Adhémar's pragmatic politics indicated a conscious desertion of Legitimism. D'Adhémar associated with the leading Legitimists of the Haute-Garonne and was scrupulous in his attendance of the annual masses of 21 January that commemorated the execution of Louis XVI, crucial Legitimist rituals, that affirmed a collective memory and a

${ }^{60}$ ADHG 1J 1370, letter, 15 Oct 1875 
collective vision of the horrors of the Revolution. Recognizing the comte de Paris as Chambord's legitimate successor no more indicated a political conversion in his case than it did in the case of Comte Albert de Mun. However, the issue is whether there was a distinctiveness to Legitimist politics. If the core of Legitimist politics was 'la défense sociale et religieuse', then perhaps we can identify d'Adhémar's politics as the politics of Legitimism. Even in the tactical interests of the comte de Paris, he was not prepared to support the anti-clerical Boulangist de Susini and even stood against him in an 1890 byelection. Likewise the platform on which Legitimists Jaffary, the marquis d'Ayguesvives (brother to the turncoat comte) and Sacaze stood as members of the list of the Union Conservatrice in 1885 laid the emphasis squarely on the menace of revolution, the violation of the liberte d'ensetgnement and religious persecution. In the clerical Aveyron, de Montéty and de Benoit were elected as part of a liste de la droite which stressed the material and moral ruin brought about by the Republic and emphasized their determination to restore the catechism and religious education in schools.

Yet these examples indicate that such principles and discourse were the common property of the right, something that made the political situation intensely problematic for the Legitimists. They viewed themselves as the natural defenders of Catholicism, a role that they had stressed after the shift in Napoleon III's Italian policy, but under the Third Republic they were to find that the other reactionary elements - from Orleanists and Bonapartists to clerical anti-republicans - were equally ready to champion the rights of the Church and the liberté d'ensetgnement. This was perfectly illustrated in the Aveyron in 1886: in the context of the lot Goblet, banning all the numerous members of the teaching orders from teaching in state schools, the reactionary notability united in a crusade against the 'écoles athées'. The Aveyron's three senators and six deputies - a mixture of Orleanists, Bonapartists and Legitimists - published a joint manifesto declaring the necessity of opening 'écoles chrétiennes' and established the Comité départemental des Écoles cbrétiennes towards which they contributed a grand total of 57,700 francs ${ }^{61}$ In view of these facts, it is tempting to take up the ideas developed by Michel Denis in his study of royalism in the Mayenne, where he argues that Legitimism lost its distinctive character to become absorbed into the broader current of conservative politics, a current that eventually led to an acceptance of 'le terrain constitutionnel'.$^{62}$ Indeed it is arguable that the Moral Order regime of 1873-7 was very conducive to such a politics; in a context where the impossibility of restoring Chambord was only too apparent, those Legitimists who were not embittered 'purs' were ready to unite with other conservatives about the fundamental issues of religious and social defence.

Yet the choice was not simply between continuing political action in alliance with other conservatives, leaving the dynastic issue to one side, and

6I A[rehives] D[épartementales de l'] A[veyron] 13T 22.

${ }^{62}$ Denis, Les royalistes 
withdrawal into the politics of fantasy, nostalgia and commemoration. Legitimism was never simply about politics, and analyses of Legitimism which imply that its essence was political fundamentally misunderstand the nature of the movement. The examples of the great Legitimists Gabriel de Belcastel and Albert de Mun, both of whom acted as parliamentary representatives, indicate that the most powerful expressions of Legitimism were often nonpolitical ${ }^{63}$ Both de Belcastel and de Mun recognized the comte de Paris as legitimate Pretender, but their actions from well before Chambord's death pointed to a less compromising mode of 'Legitimism without the Bourbons'. Both argued the case for the monarchy in similar terms. De Belcastel, speaking in 1881, declared, 'Nous qui sommes catholiques avant et pardessus tout, nous ne pouvons pas oublier les bienfaits de la Monarchie et les crimes de la Révolution', ${ }^{64}$ whilst de Mun later wrote 'J'ai été ardemment royaliste . . . Je l'ai été parce que ma foi politique trouvait, en celui qui la répresentait, l'union parfaite de mes convictions religieuses et mes conceptions sociales. ${ }^{65}$

It was above all in social activism and ultramontane Catholicism that their Legitimism expressed itself. De Belcastel was closely involved in the SacréCoeur basilica and the Voeu National movement, ${ }^{66}$ organized pilgrimages to Lourdes and, in the context of the lois Ferry, headed both the Comite de Défense des Intérêts Catboltques de la Haute-Garonne and the Oeuvre des Écoles Libres. In his La Monarchie cbrétienne, written in the wake of Chambord's death, de Belcastel selected their role in charity and Catholic education as the most memorable achievements of the Legitimist movement. ${ }^{67}$ De Mun, as a figure of national stature, served on the bureau of the Comite de Défense religieuse de Paris and was most notable for his concern with the social question, displayed in his paternalistic efforts to rechristianize the working class. His Oeuvre des cercles ouvriers, one of the first charitable movements aimed at the industrial working class, boasted a membership of 60,000 at the turn of the century, a figure that exceeded the combined total of all the socialist movements. ${ }^{68}$ The ultramontane Catholicism that de Mun shared with de Belcastel and other Legitimists led to his attempt to construct a Catholic party in 1885, an effort scotched by Pope Leo XIII's determination that Catholicism should not be represented by what was effectively a monarchist

63 For Albert de Mun B. Martin, Count Albert de Mun Paladin of tbe Tbird Republic (Chapel Hill, N C , 1978), P. Levillain, Albert de Mun catbolicisme franfais et catbolictsme romain du syllabus au ralliement (Rome, 1983).

64 De Belcastel speaking at a conference chaired by Paul Princeteau, as reported in L'Union du Midi, 28 June 1881

65 Albert de Mun's preface to Jacques Piou, Questions soclales (1910), pp iil-tv

66 The Voeu National movement was an expiatory movement shaped by the experiences of 1870-1, which sought to dedicate France to the Sacred Heart and reaffirm France's Catholic identity The Sacré-Cocur basilica, constructed on the buttes de Montmartre, was the most striking symbol of this intent.

67 Kale, Legitmism, p. 295

6 R. Tombs, France 1814-1914 (1996), p 66 
party, however sincere their beliefs. ${ }^{69}$ The intent was, however, strikingly different from the adoption of the Union Conservatrice as pursued by d'Adhémar and others. Ultimately de Mun accepted Leo XIII's exhortations and rallied to the Republic, pursuing his social agenda within the framework of the Republic, as witnessed by a law restricting women's night work passed in 1892. De Belcastel, however, never rallied to the Republic, dying in 1891 as the ralltement got under way; fittingly one of his last appearances was as an orator at the congress of the Union des Oeuvres ouvrières held at Montauban in 1889.

As should be apparent, different visions of Legitimism and the diversity of the Legitimist movement make it perfectly possible to argue that Legitimism both died before Chambord did and outlasted him. Arguably as a realistic political movement, Legitimism predeceased Chambord, The intransigent Legitimists of the comités had mostly subsided into abstention or political quiescence by 1883, despite the polemical vigour of the Legitimist press, whilst those who were to stay politically involved had already largely succumbed to the influences of the Union conservatrice. As Michel Denis persuasively argues, this element of Legitimism was in the process of being absorbed into a broader conservative politics that would represent a substantial body of anti-republican opinion throughout France. ${ }^{70}$ On the other hand, Legitimism as an emotional movement was intimately bound up with the person of Chambord. Chambord was the embodiment of the true house of France, which Legitimists honoured and celebrated with the commemorative rituals of the 21 January, the SaintHenri and the banquets held to mark Chambord's birthday. Indeed if the case for identifying Legitimism with the comte de Chambord on the grounds that it ostensibly stood for his elevation to the throne is fairly weak, the case for identifying Legitimism with Chambord in terms of the fact that their collective rituals and commemoration required him as a symbolic focus is very convincing. Such events were not incidental to Legitimism, but absolutely fundamental: the fullest accounts of the Legitimist notability of the HauteGaronne come not from records of the attendance of political meetings, but from reports on the messes du 21 janvier. ${ }^{71}$ Thus rather than reading the outpourings of the polemical press, the delegations of Vendéens, the declarations that the hour of deliverance was at hand and Cbants de Jeanne d'Arc in Chambord's last years as ridiculous or pathetic we should perhaps attempt to understand them as symbolic offerings, celebrating the cult of Chambord and the Bourbon line. In this sense Chambord was fundamental to Legitimism and if, after his death, loyalty could be transferred to the comte de Paris, this sense of quasi-religious devotion could not be. Albert de Mun later

\footnotetext{
69 The ideas of a Catholic party were strong among clertco-Legitimists. In 1889 Delpech, one of the vicatres-géneraux of the Toulouse dicocese, asked de Belcastel to persiade Émille Keller to stand as 'un candidat purement catholique' against the anti-clerical Boulangist de Susini ADHG 1J 1370 , letter s.d.

To Denis, Les royalistes

${ }^{71}$ M Simpson, 'Confronting the Revolution: French Legltimists 1877-93', unpub Ph.D. thesis (University of Londion, 2000)
} 
wrote: 'À dater de ce jour [the funeral of Chambord] il y eut place encore dans mon esprit pour l'opinion monarchique: il n'y en eut plus dans mon coeur, quel que fût mon respect pour l'héritier du droit traditionnel, pour la croyance en la monarchie ...72

The possibility of an enduring 'Legitimism without the Bourbons' was therefore to be found outside the political sphere. Legitimist ideology was concerned with society and the nature of social relations, above all social relations at the local level. The combination of ultramontane Catholicism, social concern and paternalism that de Belcastel and de Mun displayed were the social traits of Legitimism, illustrating the social ideals that Legitimists had linked to a restored Christian monarchy. This sense of Legitimism proved able to outlive Chambord, once it was uncoupled from the context of a restoration. Indeed, this line of argument can be pushed a little further. If Legitimism became focused on the social ideals, as expressed in the distinctively Legitimist movement of social Catholicism, or through a more standard interest in local charity, paternalism and good works, there was no essential need for Chambord, dead or alive. From the émigratton à l'intérleur to Chambord's death there were only really two episodes (setting aside the farcical attempt of the duchesse de Berry to restore her son by instigating a rising of the Vendée) when Legitimism was concerned with restoring Chambord - the Second Republic and 1871-3. Otherwise Legitimism was concerned with the local level and certain religious and social conceptions that perhaps had no intrinsic need of Chambord for their realization. The step from political disengagement and involvement in social and religious projects to an acceptance that Legitimist social ideals could legitimately be pursued outside the structure of the restored monarchy was not great. Paradoxically, Legitimist ideology could adapt itself to an absence of the Bourbon line. In this sense, it was only the narrow thread of Chambordist sensibility that connected 'Henri $V$ ' to his followers.

72 Albert de Mun's preface to Piou, Questions sactales, p. iv 